\title{
ANALISIS BUTIR SOAL UJIAN AKHIR SEMESTER MATEMATIKA DENGAN TEORI RESPON BUTIR
}

\author{
Devi Dwi Kurniawan
}

Universitas Selamat Sri

Email: devidwikurniawan@gmail.com

\begin{tabular}{l} 
Tersedia Online di \\
http://www.jurnal.unublitar.ac.id/ind \\
ex.php/briliant \\
\hline
\end{tabular}

\section{Sejarah Artikel}

Diterima pada 6 Mei 2019

Disetuji pada 16 Mei 2019

Dipublikasikan pada 22 Mei 2019

Hal. 215-224

\begin{tabular}{l}
\hline Kata Kunci: \\
\hline Tes Matematika, Teori Respon Butir \\
\hline
\end{tabular}

DOI:

http://dx.doi.org/10.28926/briliant.v3i 4.316
Abstrak: Studi ini bertujuan untuk melihat kualitas tes ujian akhir semester (UAS) matematika dengan teori respon butir. Penelitian ini merupakan penelitian deskriptif kuantitatif. Data yang digunakan dalam penelitian ini adalah respon siswa dalam tes bentuk pilihan ganda UAS I matematika kelas VIII SMP Pondok Modern Selamat Kabupaten Batang Tahun Pelajaran 2018/2019. Untuk melihat kualitas soal UAS I matematika dengan teori respon butir dilakukan dengan bantuan program BILOG. Pada penelitian ini analisis kualitas soal dengan teori respon butir menggunakan model dua parameter logistik (2-PL) yakni parameter daya beda (a) dan parameter tingkat kesukaran (b). Hasil analisis kualitas soal menggunakan program BILOG menunjukan bahwa dari 30 butir yang dianalisis dengan teori respon butir model dua parameter logistik terdapat 13 butir $(43,33 \%)$ yang termasuk dalam kategori butir yang baik, sedangkan 15 butir (50\%) yang termasuk kategori yang tidak baik dan 2 butir $(6,67 \%)$ yang secara otomatis gugur saat proses analisis sehingga tergolong kedalam kategori butir yang tidak baik. Kesimpulan dari hasil analisis butir soal UAS I Matematika kelas VIII SMP Pondok Modern Selamat Kabupaten Batang Tahun 2018/2019 yakni tes belum menunjukan hasil yang baik disebabkan masih banyaknya soal yang masuk dalam kategori tidak baik. Sehingga perlu ada perbaikan soal tes yang masuk kategori tidak baik dengan mengganti soal yang baru dengan kategori yang baik untuk pelaksanaan UAS I Matematika kelas VIII SMP Pondok Modern Selamat di waktu kedepan.

\section{PENDAHULUAN}

Pengukuran merupakan penetapan suatu angka dengan cara yang sistematik untuk menyatakan keadaan individu, Allen \& Yen (1979). Pemahaman tersebut dapat dimaknai pengukuran dalam bidang pendidikan dilaksanakan dalam rangka memetakan serta melihat kemampuan peserta didik setelah mengikuti proses pembelajaran disuatu jenjang satuan pendidikan sekolah dalam kurun waktu tertentu, dengan melakukan pengujian melalui tes.

Menurut Mardapi (2008) pengujian merupakan kegiatan untuk mengetahui kemampuan yang dimiliki peserta didik. Pengujian dilakukan untuk mengidentifikasi kemampuan peserta didik dan mutu pendidikan. Sesuai dengan UU No. 20 Tahun 2003 tentang Standar Nasional Pendidikan, yang wajib dijadikan acuan dasar dalam rangka pengendalian mutu pendidikan secara nasional dilakukannya evaluasi sebagai akuntabilitas penyelenggaran pendidikan kepada pihak-pihak yang berkepentingan. Berbagai bentuk pengujian yang dilaksanakan sekolah salah satunya Ujian Akhir Semester (UAS). UAS 
merupakan suatu kegiatan pengujian yang dilakukan pendidik di sekolah untuk mengetahui tingkat kemajuan peserta didik dan penilaian hasil belajar yang dilaksanakan pada akhir semester.

SMP Pondok Modern Selamat Kabupaten Batang merupakan salah sekolah yang berada di Kabupaten Batang. untuk mengetahui kemampuan siswa sekolah ini setiap akhir semester melakukan sistem pengujian menggunakan tes untuk mengukur kemampuan siswa dan ketercapaian guru dalam melakukan proses pembelajaran dalam satu semester. Anastasi \& Urbina (1997) tes prestasi belajar adalah suatu bentuk tes yang digunakan untuk mendapatkan data, sebagai bahan informasi tentang seberapa banyak pengetahuan yang telah dimiliki dan dikuasai oleh seseorang. Berdasarkan pengertian tersebut dapat dimaknai bahwa tes prestasi belajar yang dilaksanakan di SMP Pondok Modern Selamat Kabupaten Batang untuk mengetahui informasi tentang pengetahuan siswa dalam pelajaran matematika.

Soal ujian akhir semester I matematika yang digunakan untuk pengujian disusun oleh tim guru yang bernaung dalam musyawarah guru mata pelajaran matematika SMP di Kabupaten Batang, selama ini soal disusun dilakukan tanpa melakukan proses analisis soal sehingga tidak diketahui kualitas setiap butir soal yang digunakan dalam pengujian. Tujuan analisis soal adalah pengujian mutu soal yang dapat memberikan informasi tentang karakteristik soal yaitu baik buruknya soal berdasarkan analisis kuantitatif. Sesuai dengan teori tes yang berkembang hingga saat ini, dalam analisis soal didasarkan pada teori respon butir.

Teori respon butir dimaksudkan untuk mengatasi kelemahan-kelemahan pada teori tes klasik. Beberapa keterbatasan yang muncul dalam teori klasik akan menghambat usaha-usaha aplikasinya dalam mengembangkan butir soal, penyetaraan butir, dalam komparasi subyek dan lainya. Tujuan utama teori respon butir adalah melepaskan keterpisahan diantara butir uji tes dengan peserta uji tes. Ciri-ciri teori respon butir menurut Hambleton, Swaminathan, \& Rogers, (1991) adalah 1) karakteristik butir tidak tergantung peserta ujian, 2) skor yang digambarkan peserta ujian tidak tergantung pada tes, 3) merupakan model yang lebih menekankan pada tingkat butir daripada tes, 4) merupakan model yang tidak mensyaratkan secara ketat tes paralel untuk menaksirkan reliabilitas, dan 5) merupakan model yang menguraikan sebuah ukuran keputusan untuk tiap skor kemampuan yakni hubungan fungsional antara peserta tes dengan tingkat kemampuan yang dimiliki. Model matematik dalam teori respon butir, Hambleton \& Swaminathan (1985) mengatakan bahwa probabilitas subyek untuk menjawab suatu butir dengan benar tergantung pada kemampuan subyek dan karakteristik butir soal.

\subsection{Asumsi-Asumsi Teori Respon Butir}

Dalam teori respon butir ada asumsi-asumsi pendukung yang secara tidak langsung dapat diukur dan dibuktikan. Asumsi-asumsi dasar tersebut adalah unidimensi, indepensi lokal, dan kurva karakteristik butir.

\section{a.) Unidimensi}

Setiap butir tes hanya mengukur satu kemampuan, misalnya pada tes UAS pada pelajaran matematika, butir -butir yang termuat di dalamnya hanya mengukur kemampuan siswa dalam aspek matematika tertentu misal kemampuan pemecahan masalah. Oleh karena itu, asumsi unidimensi dapat ditunjukkan hanya 
jika tes mengandung satu saja komponen dominan yang mengukur prestasi belajar subjek.

\section{b.)Independensi Lokal}

Respon peserta tes pada setiap pasang butir soal adalah independen secara statistik. Dengan kata lain, asumsi independensi lokal menyatakan bahwa tidak ada korelasi antara respon peserta tes pada butir soal yang berbeda.

\section{c.) Invariansi Parameter}

Karakteristik butir soal tidak tergantung pada distribusi parameter kemampuan peserta tes dan parameter yang menjadi ciri peserta tes tidak bergantung dari ciri butir soal. Kemampuan seseorang tidak akan berubah hanya karena mengerjakan tes yang berbeda tingkat kesulitannya dan parameter butir tes tidak akan berubah hanya karena diujikan pada kelompok peserta tes yang berbeda tingkat kemampuannya.

\subsection{Model-Model Logistik Teori Respon Butir}

Ada tiga model logistik dalam teori respons butir, yaitu model logistik satu parameter (1-PL), model logistik dua parameter (2-PL), dan model logistik tiga parameter (3-PL). Perbedaan dari ketiga model tersebut pada banyaknya parameter yang digunakan dalam menggambarkan karakteristik butir dalam model yang digunakan. Dalam penelitian ini hanya menggunakan model 2-PL yakni tingkat kesukaran dan daya beda.

Model logistik dua parameter, probabilitas peserta tes untuk dapat menjawab benar suatu butir soal ditentukan oleh dua karakteristik butir, yaitu indeks kesukaran butir (bi) dan indeks daya beda butir (ai). Parameter ai merupakan indeks daya pembeda yang dimiliki butir ke-i. Pada kurva karakteristik, $a_{i}$ proporsional terhadap koefisien arah garis singgung (slope) pada titik $\theta=\mathrm{b}$. Butir soal yang memiliki daya pembeda yang besar mempunyai kurva yang sangat menanjak, sedangkan butir soal yang mempunyai daya pembeda kecil mempunyai kurva yang sangat landai. Secara teoretis, nilai $\mathrm{a}_{\mathrm{i}}$ ini terletak antara $\infty$ dan $+\infty$. Pada pada butir yang baik nilai ini mempunyai hubungan positif dengan performan pada butir dengan kemampuan yang diukur, dan $\mathrm{a}_{\mathrm{i}}$ terletak antara 0 dan 2, Hambleton \& Swaminathan (1985).

Menurut Hambleton, Swaminathan, \& Rogers (1991), secara matematis model logistik dua parameter dapat dituliskan sebagai berikut:

$$
P_{i}(\theta)=\frac{e^{D a_{i}\left(\theta-b_{i}\right)}}{1+e^{D a_{i}\left(\theta-b_{i}\right)}}
$$

Keterangan:

$\theta$ : tingkat kemampuan peserta tes

$i \quad: 1,2,3, \ldots \ldots \ldots . ., \mathrm{n}$

$P_{i}$ :probabilitas teste yang memiliki kemampuan $\theta$ menjawab butir ke-i dengan benar

: indeks kesulitan butir ke-i

$a_{i}$ : indeks daya beda butir ke-i

: bilangan transenden yang besarnya mendekati 2,718

: banyaknya butir ke-i

$D$ : faktor penskalaan yang harganya 1,7

Pada gambar 1 disajikan kurva karakteristik butir $1(\mathrm{a}=0,5 ; \mathrm{b}=0,5)$ dan butir $2(\mathrm{a}=1 ; \mathrm{b}=0,5)$. Berdasarkan gambar tersebut, jika indeks daya pembeda 
butir 1 lebih rendah dibandingkan butir 2, maka akan nampak bahwa kurva karakteristik butir 1 lebih landai dibandingkan butir 2 .

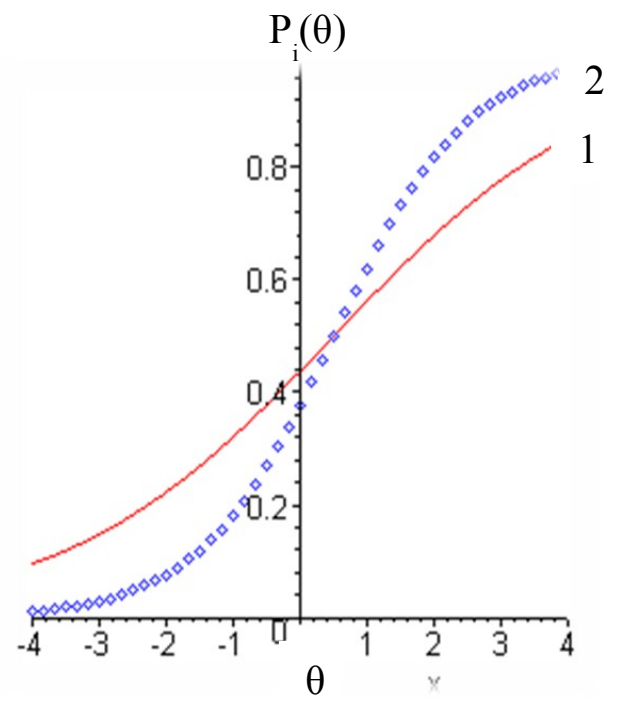

Gambar 1.

Kurva Karakteristik Butir Model 2-PL, dengan Butir $1(\mathrm{a}=0,5 ; \mathrm{b}=0,5)$ dan Butir $2(a=1 ; b=0,5)$

\subsection{Fungsi Informasi}

Fungsi informasi butir (Item Information Function) merupakan suatu metode untuk menjelaskan kekuatan suatu butir pada perangkat tes, pemilihan butir tes, dan pembandingan beberapa perangkat tes. Fungsi informasi buti menyatakan kekuatan atau sumbangan butir tes dalam mengungkap latent trait yang diukur dengan tes tersebut. Dengan fungsi informasi butir diketahui butir yang mana yang cocok dengan model sehingga membantu dalam seleksi butir tes. Secara matematis, fungsi informasi butir memenuhi persamaan sebagai berikut Hambleton, Swaminathan, \& Roger [5]:

$$
I_{i}(\theta)=\frac{\left[P_{i}^{\prime}(\theta)\right]^{2}}{P_{i}(\theta) Q_{i}(\theta)}
$$

Keterangan rumus:

i $: 1,2,3, \ldots, \mathrm{n}$

$I_{i}(\theta) \quad$ : fungsi informasi suatu perangkat tes.

$P_{i}(\theta)$ : peluang peserta dengan kemampuan $\theta$ menjawab benar butir ke-i

$P_{i}^{\prime}(\theta)$ : turunan fungsi $P_{i}(\theta)$ terhadap $\theta$

$Q_{i}(\theta)$ : peluang peserta dengan kemampuan $\theta$ menjawab salah butir ke-i

Fungsi informasi tes merupakan jumlah dari fungsi informasi butir penyusun tes tersebut Hambleton, Swaminathan, \& Rogers (1991). Berdasarkan hal ini, fungsi informasi perangkat tes akan tinggi jika butir tes mempunyai fungsi informasi yang tinggi pula. Fungsi informasi perangkat tes secara matematis dapat ditulis sebagai berikut.

$$
I(\theta)=\sum_{i=1}^{n} I_{i}(\theta)
$$


Nilai-nilai indeks parameter butir dan kemampuan peserta tes merupakan hasil estimasi. Karena merupakan hasil estimasi, maka kebenarannya bersifat probabilitas dan tidak terlepas dengan kesalahan pengukuran. Dalam teori respon butir, kesalahan baku pengukuran (Standard Error of Measurement ,SEM) memiliki hubungan yang erat dengan fungsi informasi. Fungsi informasi dengan SEM mempunyai hubungan dengan berbanding terbalik kuadratik, semakin besar fungsi informasinya maka SEM semakin kecil dan sebaliknya, Hamleton, Swaminathan, \& Rogers (1991). Secara sistematis rumus tersebut dapat ditulis :

$$
\operatorname{SEM}(\theta)=\frac{1}{\sqrt{I(\theta)}}
$$

Keterangan:

$\operatorname{SEM}(\theta)$ : kesalahan baku dalam pengukuran

: harga fungsi informasi tes terhadap paramater tingkat kemampuan peserta tes.

: Tingkat kemampuan peserta tes.

Kesalahan baku teori respons butir dalam pengukuran berpatokan pada fungsi informasi suatu tes, semakin besar fungsi informasi suatu tes maka semakin kecil kesalahan baku pengukuran. Sehingga dapat disimpulkan bahwa besar kecilnya nilai fungsi informasi suatu tes sangat mempengaruhi kesalahan baku pengukuran. Semakin besar fungsi informasi maka tes tersebut cermat dalam mengukur kemampuan peserta tes. Kecermatan hasil ukur yang ditunjukan dengan lebar sempitnya interval kepercayaan bagi kemampuan peserta yang sebenarnya.

\section{METODE PENELITIAN}

Penelitian ini merupakan jenis penelitian deskriptif kuantitatif dengan data berupa perangkat soal ujian akhir semester dan lembar jawaban siswa kelas VIII SMP Pondok Modern Selamat Kabupaten Batang. Penelitian deskriptif kuantitatif dilakukan dengan tujuan untuk melihat kualitas tes matematika UAS.

Populasi dalam penelitian ini adalah seluruh siswa yang mengikuti ujian akhir semester I matematika kelas VIII SMP Pondok Modern Selamat Kabupaten Batang. Sampel dalam penelitian ini adalah respon siswa dalam UAS I matematika yang berjumlah 124 siswa yang terbagi kedalam 4 kelas yakni kelas VIII A berjumlah 31 siswa, kelas VIII B berjumlah 32 siswa, kelas VIII C berjumlah 30 siswa dan kelas VIII D berjumlah 31 siswa. Seluruh siswa pada hari senin tanggal 6 Desember 2018 telah mengikuti ujian akhir semeste (UAS) I mata pelajaran matematika. Hasil tes siswa akan dianalisis untuk melihat kualitas soal yang digunakan dalam UAS I matematika.

Teknik pengumpulan data dalam penelitian ini dilakukan menggunakan teknik dokumentasi berupa soal dan respon siswa dalam UAS I matematika kelas VIII SMP Pondok Modern Selamat Kabupaten Batang. Analisis soal UAS I matematika berdasarkan teori respon butir model dua parameter logistik (2-PL) yang dilakukan menggunakan bantuan program Bilog-Mg versi 3.0.

\section{HASIL PENELITIAN DAN PEMBAHASAN}

Analisis soal UAS I matematika siswa kelas VIII SMP Pondok Modern Selamat Kabupaten Batang Tahun Pelajaran 2018/2019 dilakukan menggunakan bantuan program Bilog-Mg versi 3.0. Analisis ini menggunakan model dua parameter logistik (2PL). Dari model tersebut diketahui kualitas soal ujian akhir 
semester (UAS) I matematika SMP Pondok Modern Selamat Kabupaten Batang Tahun Pelajaran 2018/2019.

Hasil analis model logistik 2PL melibatkan dua parameter butir yaitu tingkat kesukaran butir dan daya beda. Hasil analisis butir soal pada model logistik dua parameter adalah sebagai berikut.

Tabel 1. Distribusi Kategorisasi Parameter Butir Model 2PL

\begin{tabular}{|l|l|l|}
\hline Daya Beda (a) & Frekuensi & Persentase (\%) \\
\hline Keterangan & 28 & 100 \\
\hline Baik & 0 & 0 \\
\hline Tidak Baik & 28 & 100 \\
\hline Total & Frekuensi \\
\hline Tingkat Kesukaran (b) & 18 & Persentase (\%) \\
\hline Keterangan & 10 & 64,29 \\
\hline Baik & 28 & 35,71 \\
\hline Tidak Baik & \multicolumn{2}{|l|}{} \\
\hline Total & Frekuensi & 100 \\
\hline Kesesuaian Model (Fit Model) & Persentase (\%) \\
\hline Keterangan & 21 & 75 \\
\hline Fit model & 7 & 25 \\
\hline Tidak fit model & 28 & 100 \\
\hline Total &
\end{tabular}

Berdasarkan Tabel 3 di atas, diketahui bahwa untuk daya beda (a) terdapat 28 butir termasuk baik (100\%). Tingkat kesukaran butir (b) terdapat 18 butir termasuk baik $(64,29 \%)$ dan 10 butir $(35,71)$ tidak baik. Sedangkan untuk kesesuaian butir (fit model) terdapat 21 butir termasuk fit model (75\%) dan 7 butir $(25 \%)$ tidak fit model.

Tabel 2. Hasil Estimasi Parameter Butir Model Dua Parameter (2PL)

\begin{tabular}{|c|c|c|c|c|c|c|c|}
\hline \multirow{2}{*}{ Butir } & \multicolumn{2}{|c|}{ Daya Beda } & \multicolumn{2}{|c|}{ Tingkat Kesukaran } & \multicolumn{2}{|c|}{ Chi-Squared } & \multirow{2}{*}{ Keterangan } \\
\hline & $\mathbf{A}$ & Keterangan & $\mathbf{B}$ & Keterangan & p-value & Keterangan & \\
\hline Butir01 & 0,335 & Baik & 1,901 & Baik & 0,0143 & Tidak fit model & Tidak Baik \\
\hline Butir02 & 0,712 & Baik & 0,206 & Baik & 0,0623 & Fit model & Baik \\
\hline Butir03 & 0,385 & Baik & $-2,124$ & Tidak baik & 0,0955 & Fit model & Tidak Baik \\
\hline Butir04 & 0,442 & Baik & $-1,453$ & Baik & 0,6198 & Fit model & Baik \\
\hline Butir05 & 0,285 & Baik & 0,848 & Baik & 0,4476 & Fit model & Baik \\
\hline Butir06 & 1,266 & Baik & 1,160 & Baik & 0,6133 & Fit model & Baik \\
\hline Butir07 & 0,581 & Baik & 0,571 & Baik & 0,3700 & Fit model & Baik \\
\hline Butir08 & 0,287 & Baik & $-2,658$ & Tidak baik & 0,0056 & Tidak fit model & Tidak Baik \\
\hline Butir09 & 0,364 & Baik & $-3,997$ & Tidak baik & 0,8864 & Fit model & Tidak Baik \\
\hline Butir10 & 0,645 & Baik & 0,373 & Baik & 0,2314 & Fit model & Baik \\
\hline Butir11 & 0,394 & Baik & $-2,581$ & Tidak baik & 0,7604 & Fit model & Tidak Baik \\
\hline Butir12 & & \multicolumn{6}{|c|}{ Butir Gugur Saat Analisis } \\
\hline Butir13 & 0,321 & Baik & 4,167 & Tidak baik & 0,4591 & Fit model & Tidak Baik \\
\hline Butir14 & 0,628 & Baik & 0,536 & Baik & 0,0002 & Tidak fit model & Tidak Baik \\
\hline Butir15 & 0,649 & Baik & $-0,764$ & Baik & 0,5752 & Fit model & Baik \\
\hline Butir16 & 0,338 & Baik & 2,045 & Tidak baik & 0,1581 & Fit model & Tidak Baik \\
\hline Butir17 & & \multicolumn{5}{|c|}{ Butir Gugur Saat Analisis } & \\
\hline
\end{tabular}




\begin{tabular}{|l|l|l|l|l|l|l|l|}
\hline Butir18 & 0,330 & Baik & $-1,351$ & Baik & 0,1747 & Fit model & Baik \\
\hline Butir19 & 0,444 & Baik & 2,257 & Tidak baik & 0,3263 & Fit model & Tidak Baik \\
\hline Butir20 & 0,329 & Baik & 0,113 & Baik & 0,0123 & Tidak fit model & Tidak Baik \\
\hline Butir21 & 0,341 & Baik & $-2,630$ & Tidak baik & 0,4173 & Fit model & Tidak Baik \\
\hline Butir22 & 0,790 & Baik & 2,352 & Tidak baik & 0,5456 & Fit model & Tidak Baik \\
\hline Butir23 & 0,458 & Baik & 1,394 & Baik & 0,0071 & Tidak fit model & Tidak Baik \\
\hline Butir24 & 1,226 & Baik & 2,062 & Tidak baik & 0,0000 & Tidak fit model & Tidak Baik \\
\hline Butir25 & 0,700 & Baik & 1,274 & Baik & 0,2651 & Fit model & Baik \\
\hline Butir26 & 0,234 & Baik & 1,933 & Baik & 0,2228 & Fit model & Baik \\
\hline Butir27 & 1,697 & Baik & 1,195 & Baik & 0,0000 & Tidak fit model & Tidak Baik \\
\hline Butir28 & 0,670 & Baik & 1,265 & Baik & 0,1416 & Fit model & Baik \\
\hline Butir29 & 0,297 & Baik & 1,029 & Baik & 0,5060 & Fit model & Baik \\
\hline Butir30 & 0,313 & Baik & $-1,561$ & Baik & 0,5528 & Fit model & Baik \\
\hline Rerata & $\mathbf{0 , 5 5 2}$ & & $\mathbf{0 , 2 7 0}$ & & $\mathbf{0 , 3 0 3}$ & & \\
\hline
\end{tabular}

Berdasarkan dari Tabel 2 di atas, jumlah butir yang layak dianalisis menggunakan teori respons butir model 2PL adalah dari 28 butir soal. Rerata tingkat kesukaran butir $(b)$ sebesar 0,270 yang termasuk dalam kategori baik. Sedangkan rerata daya beda (a) sebesar 0,552 termasuk dalam kategori baik.

Estimasi paremeter butir $b_{i}$ dari ke-28 butir tersebut, terdapat 18 butir termasuk kekategori tingkat kesukaran yang baik dan terdapat 10 butir memiliki tingkat kesukaran yang tidak baik. Hal ini terlihat dari hasil estimasi parameter $b_{i}$ yang tidak berada diantara $-2 \leq b_{i} \leq 2$. Lima butir soal yang termasuk sangat sulit yaitu butir $13(4,167)$, butir $16(2,045)$, butir $19(2,257)$, butir $22(2,352)$ dan butir 24 (2,062). Empat item ini memilki nilai tingkat kesukaran $>2$, sehingga termasuk dalam kategori butir soal yang sulit. Sedangkan lima butir soal yang termasuk sangat mudah yaitu butir $3(-2,124)$, butir $8(-2,658)$, butir $9(-3,997)$, butir $11(-2,581)$ dan butir $21(-2,630)$. Lima butir ini memiliki tingkat kesukaran yang sangat mudah karena memiliki nilai tingkat kesukaran $<-2$, sehingga termasuk dalam kategori butir soal yang mudah. Selanjutnya untuk kecocokan model, terdapat 7 butir yang termasuk butir tidak cocok dengan model (2PL) yaitu butir $1(0,0143)$, butir $8(0,0056)$, butir $14(0,0002)$, butir $20(0,0123)$, butir $23(0,0071)$, butir $24(0,0000)$ dan butir $27(0,0000)$. Hal ini disebabkan karena nilai signifikansi ( $p$-value) dari chi squared di bawah taraf signifikansi 0,05.

Hasil informasi parameter di atas, maka dapat dijadikan informasi dalam menentukan butir-butir mana yang memiliki karakteristik butir yang baik. Butir yang baik hendaknya memenuhi tiga persyaratan yaitu memiliki tingkat kesukaran yang baik $\left(-2 \leq b_{i} \leq 2\right)$, daya beda yang baik $\left(0 \leq a_{i} \leq 2\right)$ dan butir cocok dengan model. Berdasarkan hal tersebut maka dari 28 butir terdapat 13 butir $(43,29 \%)$ yang termasuk dalam karakteristik butir yang baik yaitu butir 2, 4, 5, 6, 7, 10, 15, $18,25,26,28,29$ dan 30. Hasil analissi tersebut terlihat bahwa hanya terdapat 13 butir yang baik dari 28 butir, hal ini menujukan hasil yang kurang efeektif. Ariyana (2011) mengemukakan dalam hasil penelitiannya bahwa peserta tes juga sangat mempengaruhi hasil dari analisis soal. Jumlah peserta tes atau responden sangat berpengaruh terhadap hasil analisis tes. Dari hasil analisis di atas serta didukung hasil penelitian yang lain dapat disimpulkan bahwa penyebab sedikitnya butir soal yang baik juga disebabkan oleh kemampuan peserta tes. 
Penjelasan mengenai grafik ICC atau kurva karakteristik butir, fungsi informasi butir, fungsi informasi tes dan standard error measurement (SEM) pada model logistik dua parameter (2PL) adalah sebagai berikut ini.

\section{1) ICC dan Fungsi Informasi Butir Model Dua Parameter (2PL)}

Berikut adalah salah satu contoh grafik ICC dan fungsi informasi butir pada analisis butir Soal UAS I Matematika Siswa Kelas VIII SMP Pondok Modern Selamat Tahun Pelajaran 2018/2019 dengan menggunakan model 2PL.
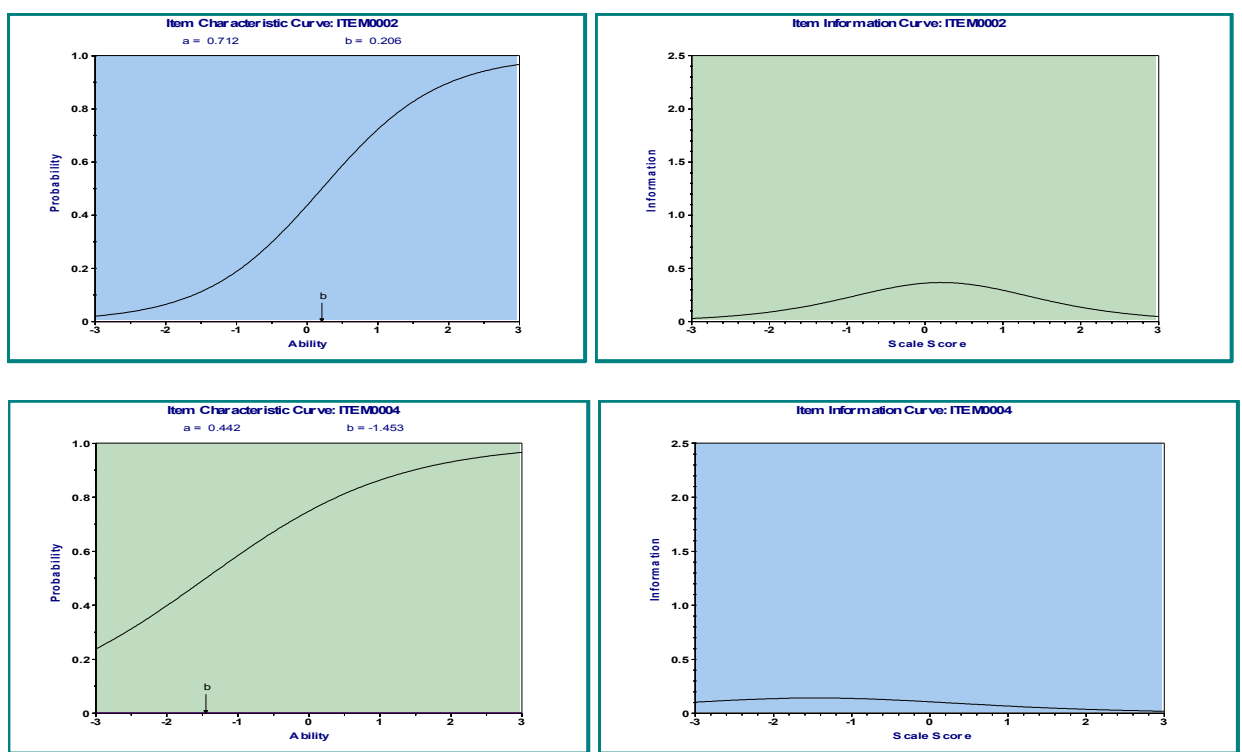

\section{Gambar 2. ICC dan Fungsi Informasi Butir Model 2PL}

Model 2PL hanya melibatkan dua parameter butir yaitu tingkat kesukaran (b) dan daya beda (a). Berdasarkan Gambar 2 di atas, diketahui nilai $a_{2}$ pada butir 2 yaitu 0,712 dengan nilai $b_{2}$ sebesar 0,206 dan nilai $a_{4}$ pada butir 4 yaitu 0,442 dengan nilai $b_{4}$ sebesar $-1,453$. Berdasarkan hal tersebut diketahui bahwa nilai daya beda $\left(a_{2}\right)$ untuk butir 2 lebih rendah dari butir $4\left(a_{4}\right)$, sehingga ICC pada butir 2 akan tampak lebih landai dibandingan butir 4 . Nilai $b_{2}=0,206$ dapat diartikan bahwa diperlukan kemampuan minimal 0,206 pada skala untuk menjawab dengan benar butir 2 dengan peluang 50\%. Fungsi informasi butir $2\left(I_{2}\right)$ akan maksimal ketika pada skala 0,206. Sama halnya dengan butir 2, butir 4 nilai $b_{4}=-1,453$ dapat diartikan bahwa diperlukan kemampuan minimal $-1,453$ pada skala untuk menjawab dengan benar butir 4 dengan peluang $50 \%$.

\section{2) Fungsi Informasi Tes dengan Standard Error Measurement (SEM) Pada Model 2PL}

Grafik hubungan antara fungsi informasi tes dengan SEM pada model 2PL ditunjukkan oleh Gambar 3 berikut ini. 


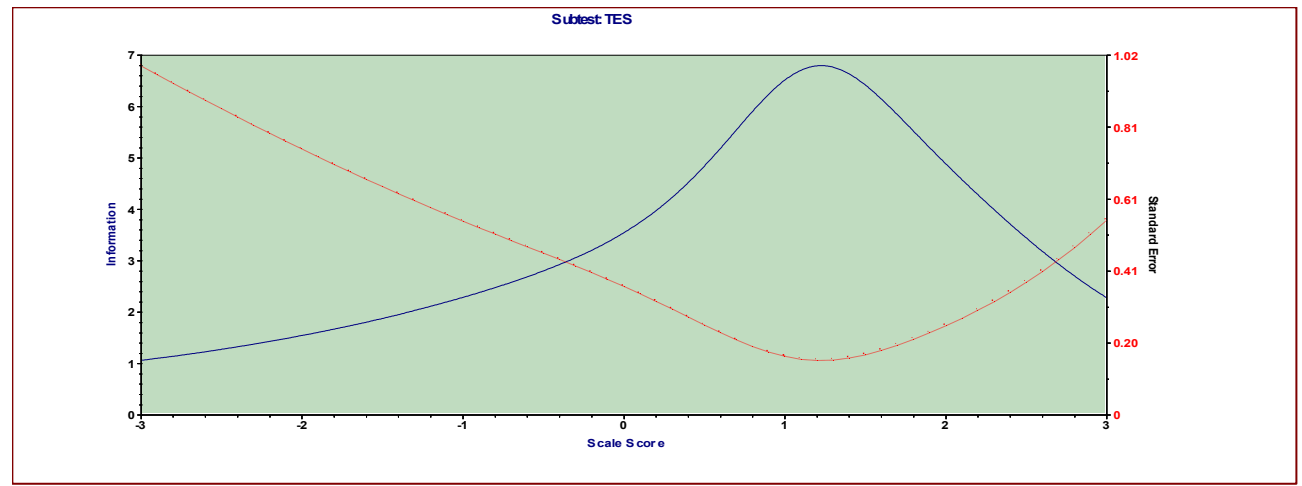

Gambar 3. Fungsi Informasi Tes dengan SEM Model 2PL

Berdasarkan Gambar 3 di atas, diketahui bahwa Soal UAS I Matematika Siwa Kelas VIII SMP Pondok Modern Selamat Kabupaten Batang Tahun Pelajaran 2018/2019 yang dikembangkan mampu memberikan informasi yang baik terhadap kemampuan siswa yang berkemampuan -2,5 dampai dengan $+1,2$. $S E M$ terkecil terjadi pada saat perangkat tes tersebut memberikan fungsi informasi tes yang maksimal.

\section{KESIMPULAN}

Analisis butir soal UAS I matematika SMP Pondok Modern Selamat Kabupaten Batang dengan Teori Respon Butir Model model dua parameter logistik (2-PL) didapatkan dari 30 butir terdapat 13 butir (43,33\%) yang termasuk dalam karakteristik butir yang baik yaitu butir 2, 4, 5, 6, 7, 10, 15, 18, 25, 26, 28, 29 dan 30. Sedangkan 15 butir $(50,00 \%)$ yang tergolong butir tidak baik yaitu butir 1, 3, 8, 9, 11, 13, 14, 16, 19, 20, 21, 22, 23, 24, dan 27. Selanjutnya terdapat 2 butir $(6,67 \%)$ yang secara otomatis gugur saat analisis sehingga tergolong kedalam butir tidak baik yaitu butir 12 dan 17 .

\section{SARAN}

Soal tes UAS I Matematika kelas VIII SMP Pondok Modern Selamat Kabupaten Batang Tahun 2018/2019 belum menunjukan hasil yang baik disebabkan masih banyaknya soal yang masuk dalam kategori tidak baik. Sehingga perlu ada perbaikan soal tes yang masuk kategori tidak baik dengan mengganti soal yang baru dengan kategori yang baik untuk pelaksanaan UAS I Matematika kelas VIII SMP Pondok Modern Selamat di waktu kedepan.

\section{DAFTAR PUSTAKA}

Allen, Mary J., \& Yen, Wendy M. (1979). Introduction To Measurement Theory. California: Brooks/Cole Publishing Company.

Anastasi, A., \& Urbina, S. (1997). Tes Psikologi. (Edisi Bahasa Indonesia), Jilid 1. Jakarta: Prenhallindo

Mardapi, Djemari. (2008). Teknik Penyusunan Instrumen Tes dan Non Tes. Yogyakarta: Mitra Cendikia Press. 
Hamblenton, R.K. dan Swaminathan, H. (1985). Item response theory. Boston, MA: Kluwer Inc.

Hamblenton, R.K., Swaminathan, H. \& Rogers, H.J. (1991). Fundamental of item response theory. Newbury Park, CA: Sage Publication Inc.

Ariyana, Lilis Tri. (2011). Analisis Butir Soal Ulangan Semester Gasal IPA Kelas IX SMP di Kabupaten Grobokan. Semarang: Fakultas Matematika dan Ilmu Pengetahuan Alam Universitas Negeri Semarang.

UU No. 20 Tahun 2003 tentang Standar Nasional Pendidikan. 